\title{
Effect of Boron on the Structure and Some Physical Properties of Plain Cast Irons
}

\author{
By Alexander I. Krynitsky and Harry Stern
}

\begin{abstract}
The effects of boron additions, ranging from 0.001 to 0.48 percent, on the properties of various gray cast irons were determined by casting chill plates, wedge castings, and arbitration bars. Cooling eurve data indicated that during solidification boron produced an undercooling effect, which increases with increasing boron content. Boron increases the depth of chill in chill plates and wedges, as well as the hardness of arbitration bars and chill plates. Boron decreases the size and quantity of graphite, increases the free carbide content, and tends to increase the amount of eutectic structure. "Structureless" envelopes around the pearlite islands and "structureless islands" in the cementite matrix accompany an increase in the boron content.
\end{abstract}

\section{Introduction}

The element boron lies between beryllium and carbon in the periodic table and has the atomic number 5 . It falls in the third group and possesses a relatively small atomic radius (approximately 1 A) [1]. ${ }^{1}$ These characteristics of boron suggest its similarity to carbon. This similarity has been emphasized by Tschischewsky [2], who observed a pearlitic constituent in iron-boron alloys and called it "boric pearlite." The existence of iron boride, $\mathrm{Fe}_{2} \mathrm{~B}$, containing 8.83 percent of boron, appears to be fairly well established. This boride is soluble to some degree in delta, gamma, and alpha iron, but investigators disagree as to the limit of solid solubility. Thus, the iron-boron constitution diagram ${ }^{2}$ in the Metals Handbook [3] indicates that the boron solubility is less than 0.15 percent at $915^{\circ} \mathrm{C}$, and decreases with decreasing temperature to about 0 percent at $700^{\circ} \mathrm{C}$. However, the diagram in the International Critical Tables shows a boron solubility of 0 percent at $900^{\circ} \mathrm{C}$ and an increasing solubility with decreasing temperature reaching a maximum of about 0.2 percent at $700^{\circ} \mathrm{C}$.

${ }_{1}^{1}$ Figures in brackets indicate the literature references at the end of this paper.

${ }^{2}$ The Metals Handbook diagram (page 1182) is essentially Hansen's [4] diagram, which is a composite diagram of those presented by Hannesen [5], Tschischewsky [2], and Wever and Muller [6].
The equilibrium diagram of the iron-cartonboron alloys as determined by Vogel and Tammann [7] is shown in figure 1 (the shaded area was incorporated by the authors and will be referred to later). Vogel and Tammann state that the limit of solid solubility of boron in alpha iron at room temperature is 0.08 percent and the ternary solid solution $\mathrm{Fe}_{-} \mathrm{Fe}_{3} \mathrm{C}-\mathrm{Fe}_{2} \mathrm{~B}$ transforms, when cooling to room temperature, into pearlite composed of two solid solutions $\mathrm{FeB}$ and $\mathrm{Fe}_{3} \mathrm{C}$ $\mathrm{Fe}_{2} \mathrm{~B}$.

The effect of boron on the properties and behavior of ferrous metals received a little attention in the early 1920's when Burgess and Woodward [8] reported difficulties in the hot-rolling of steels, that contained 0.49 percent of boron, and Walter [9] stated that iron, steel, and their alloys containing boron in amounts of 0.2 to 2 percent were too hard and brittle to be of value.

Interest in the effect of boron additions to ferrous metals has received increasing attention since about 1940. Schwartz [10], Tisdale [11], and Joly [12] showed that additions of approximately 0.001 to 0.003 percent of boron improved the annealing behavior of malleable iron. Schwartz [13] showed that additions (not to be confused with recoveries) of 0.1 and 0.04 percent of boron to white iron enormously increased the 
graphitizing rate measured at $900^{\circ} \mathrm{C}$, but that 0.88 percent of boron prevented graphitization.

Bastien and Guillet [14] studied the effect of 0.046 to 0.385 percent of boron in cast iron that contained 3.09 to 3.65 percent of total carbon, about 1.45 percent of silicon, 0.45 percent of manganese, 0.06 percent of phosphorus, and 0.01 percent of sulfur. Their results showed that the number of graphite particles decreased with increasing boron, this diminution becoming pronounced at 0.18 percent of boron. At the same time the length and thickness of the graphite flakes tended to decrease and accumulate in "colonies." Boron also was found to retard graphitization during annealing by slowing down the speed of decomposition of cementite. They stated that the depth of chill decreased for boron additions up to 0.1 percent and ther increased uniformly. They further reported that boron raises the hardness, transverse strength, modulus of elasticity, and shear strength of gray cast irons but reduces their capacity for deformation. It was also shown that boron uniformly and rapidly raises the cementite Curie point, $A_{0}$ (cementite magnetic transformation point), a result that confirms the existence of the complex cementite $\mathrm{Fe}_{3} \mathrm{C}-\mathrm{Fe}_{2} \mathrm{~B}$ postulated by Vogel and Tammann [7].

The work of the investigators cited in most cases suggests that iron forms a compound with boron of the composition $\mathrm{Fe}_{2} \mathrm{~B}$ and, in combination with carbon, probably forms a complex cementite $\mathrm{Fe}_{3} \mathrm{C}-\mathrm{Fe}_{2} \mathrm{~B}$. It is also probable that in the borontreated irons $\mathrm{Fe}-\mathrm{B}$ solid solution may be present per se or as part of the pearlite composed of the two solid solutions $\mathrm{Fe}-\mathrm{B}$ and $\mathrm{Fe}_{3} \mathrm{C}-\mathrm{Fe}_{2} \mathrm{~B}$.

\section{Scope of Investigation}

The purpose of the present investigation was to secure additional information on the effect of boron on certain significant properties of plain gray irons. Nine different stock irons, of the compositions given in table 1 , were used. These irons were remelted, and boron in amounts up to 0.48 percent was added. The range of carbon and boron contents in the melts thus prepared falls within the limits of the shaded portion of the ternary diagram in figure 1 . The effects of boron additions on the transverse-test properties, depth of chill, hardness, solidification characteristics, and structure of these cast irons were studied.

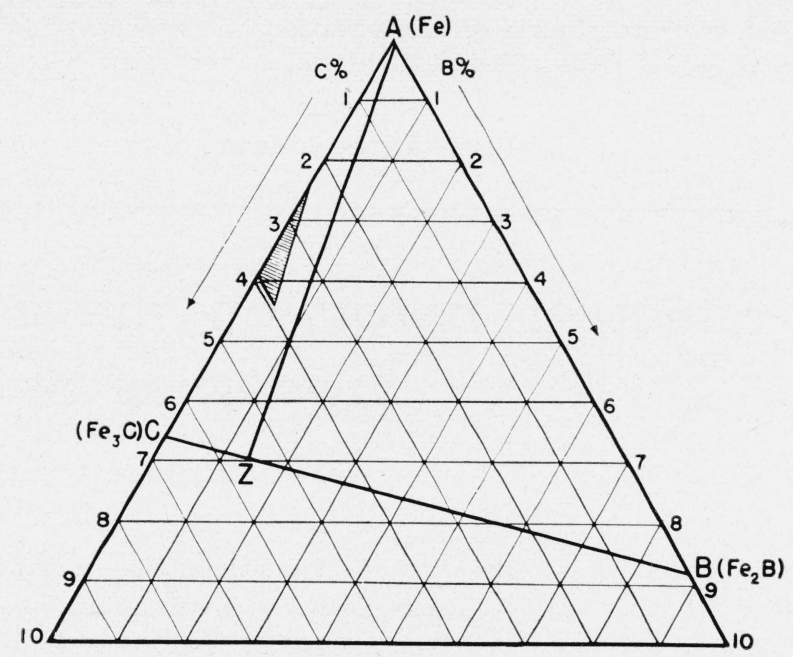

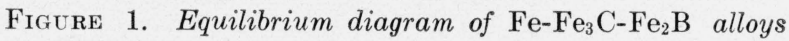
at room temperature, Vogel and Tammann [7]

Shaded portion indicates the range of the carbon and boron contents of the irons studied.

\section{Preparation of Specimens}

\section{Irons}

There was considerable variation in the analyses of different pigs of the same lot of stock iron used in this investigation, except for lots B, C, D-107, and $\mathrm{G}-137$. Therefore, the analyses given in table 1 are average values in many cases. Irons $\mathrm{B}$ and $\mathrm{C}$ were specially prepared pig irons and the pigs were of uniform composition. Irons D-107 and $\mathrm{G}-137$ were prepared from pig irons $\mathrm{D}$ and $\mathrm{G}$ remelted to improve their chemical homogeneity. It is noteworthy that the stock pig irons used in this investigations contained from 0.001 to 0.006

TABLE 1. Composition of basic pig irons used in preparing heats with different boron contents

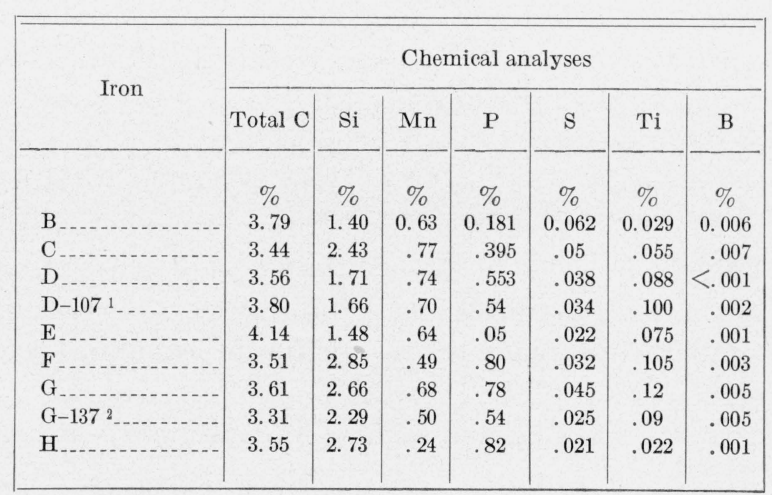

${ }^{1}$ Remelted iron D.

${ }^{2}$ Remelted iron $\mathrm{G}$. 
percent of boron (table 1) before any experimental additions of this element were made. Appreciable amounts of titanium, ranging from 0.022 to 0.12 percent, were also present in these irons.

Boron additions in the present work were made in the form of ferroboron containing: $\mathrm{B}, 11.71$; $\mathrm{C}$, 0.60 ; Si, 4.04; P. 0.020 ; S, trace; Fe, 83.63 percent. Proprietary alloys, which contain boron generally employed for boron additions to steel [15], were not used because they contain large amounts of other elements, such as nickel, titanium, silicon, zirconium, etc. The results of the chemical analyses of different heats of the boron-treated and untreated irons showed a consistent decrease of carbon with an increase in the boron content; phosphorus remained practically unchanged. Silicon, manganese, and sulfur contents varied, although not consistently with changes in boron contents.

In a number of cases the scrap remaining from a boron-treated heat was remelted one or more times for additional specimens. Results of chemical analyses showed that no significant loss in boron occurred during remelting operations. Digges and Reinhart [16] have reported that appreciable amounts of boron were retained in steels after remelting in an induction furnace under normal and highly oxidizing conditions.

\section{Molds}

Green, dry, and core sands were used in preparing the molds. The green-sand mixture consisted of eight parts of Lumberton molding sand and one part of sea-coal, tempered to approximately 7 percent water content. The average properties of this sand mixture, tested according to American Foundrymen's Society specifications are as follows: Permeability number 40, green compressive strength, $12 \mathrm{lb} / \mathrm{in}^{2}{ }^{2}$, A. F. S. standard hardness number 80 . For the same sand mixture in the dried condition, permeability was 55 and dry compressive strength $120 \mathrm{lb} / \mathrm{in}^{2}$ Core sand for molds and skim gates contained by volume approximately 83 percent of silica sand A. F. S. grain-fineness 90 to $120,2.5$ percent of corn-flour binder (Mogul), 1.0 percent of linseed oil, 14.0 percent of silica flour, 0.5 percent of Western bentonite, and 0.5 percent of kerosine.

The core sand molds were baked at $425^{\circ}$ to $450^{\circ} \mathrm{F}, 75$ minutes for each 1 -in. cross section. In this condition the permeability of the sand was 28 and the compressive strength $830 \mathrm{lb} / \mathrm{in}^{2}$.

\section{Specimens}

The transverse properties were determined on cylindrical bars $1.2 \mathrm{in}$. in diameter with an 18-in. span. At the beginning of the investigation these bars were bottom poured in green sand molds in groups of four. However, it was found that bars with a high boron content cast in this manner developed shrinkage cavities appearing along the longitudinal axes. Therefore, the mold design was changed, to accommodate top-pouring in individual molds made of core sand and baked. Four of these molds were assembled (fig. 2) in a flask, heap sand rammed tightly around them, and a common pouring basin cut to permit simultaneous pouring. Each mold was provided with its own filter gate, $2 \frac{1}{2}$-in. outside diameter $3 / 4$ in. thick with a $5 / 16$-in. diameter central hole. Figure 3 shows the bars as

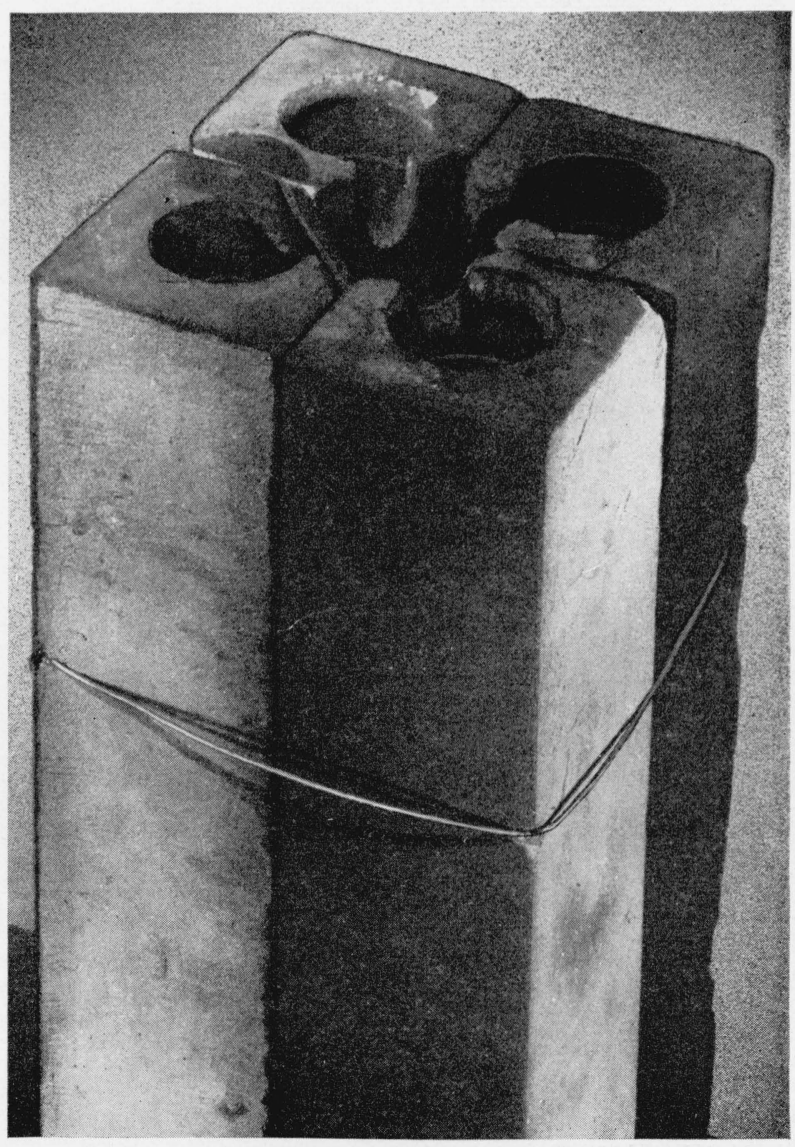

Figure 2. Dry core sand molds assembly used for the 1.2-in. transverse-test bars. 


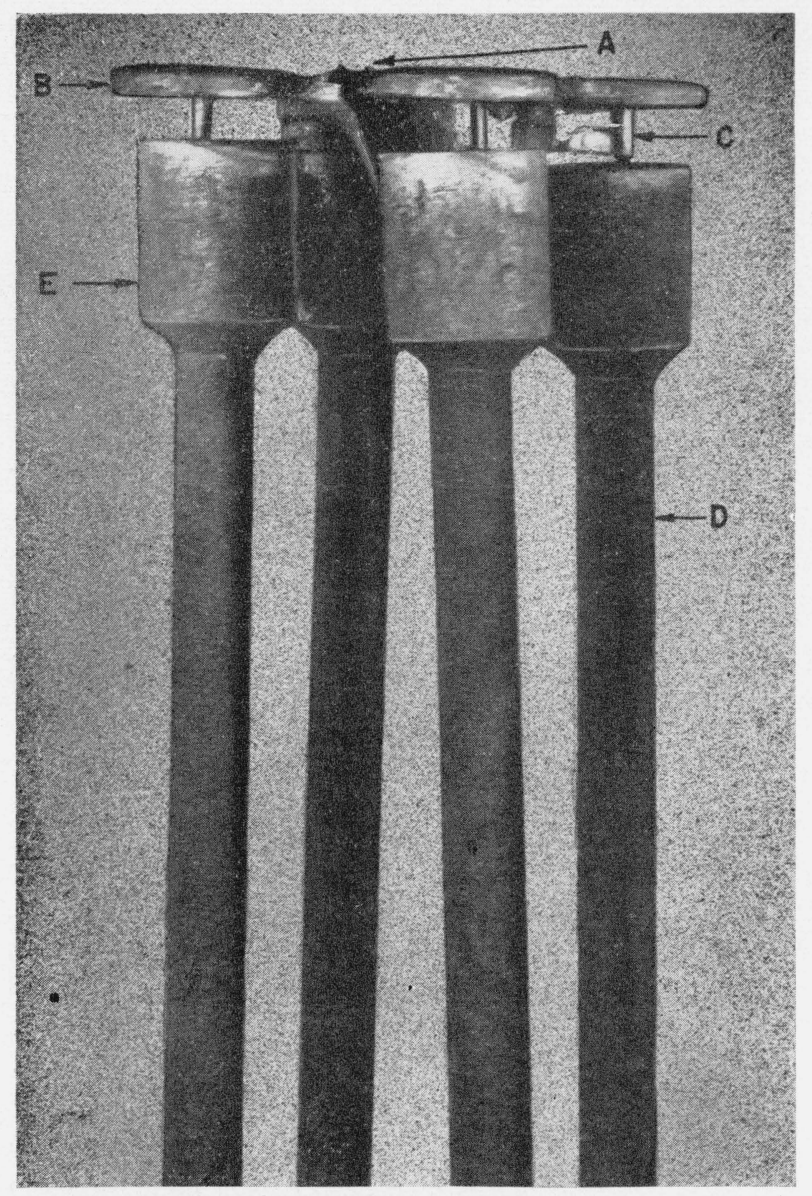

Figure 3. Transverse-test bars $1.2 \mathrm{in}$. in diameter, as cast in dry-core sand mold.

A, Pouring basin; B, top gates; C, filter gates; D, vertically top-poured bars; $\mathrm{E}$, heads.

cast. All test bars were allowed to cool in the molds for approximately 20 hours before being removed.

Plate specimens 4 by 4 by $1 / 2$ in. (fig. 4 ), and wedge specimens $2 \frac{1}{2} \mathrm{in}$. wide at the base, $3 \mathrm{in}$. high and $4 \mathrm{in}$. long (fig. 5), were used to evaluate the influence of boron on the susceptibility to chill. The plate specimens (fig. 4), were cast with the bottom side in contact with a heavy iron chill block. The wedge specimens (fig. 5) were cast into dry sand molds. Keyhole-type specimens were not found suitable for these tests.

In the initial part of the investigation, the plates were cast in green-sand molds; subsequently dry sand molds were used. These latter were prepared by drying the assembly of mold and chill block in a core oven at approximately $425^{\circ} \mathrm{F}$. $\left(218^{\circ}\right.$ C.) for about $4 \mathrm{hr}$ and cooling to room temperature. The plates and wedge specimens were cast from each heat to measure the chill characteristics of the various compositions. However, the plates could not be used as a criterion of susceptibility to chill for irons which possessed a high chilling tendency, since they became white throughout the entire depth of the plates. For such irons the chill depth was measured on the slower cooling wedge. The plates and wedges were removed from the molds $20 \mathrm{~min}$ after pouring and allowed to cool to room temperature before being fractured.

\section{Casting Procedure}

The irons were melted in two types of highfrequency induction furnaces, a 300-lb tilting

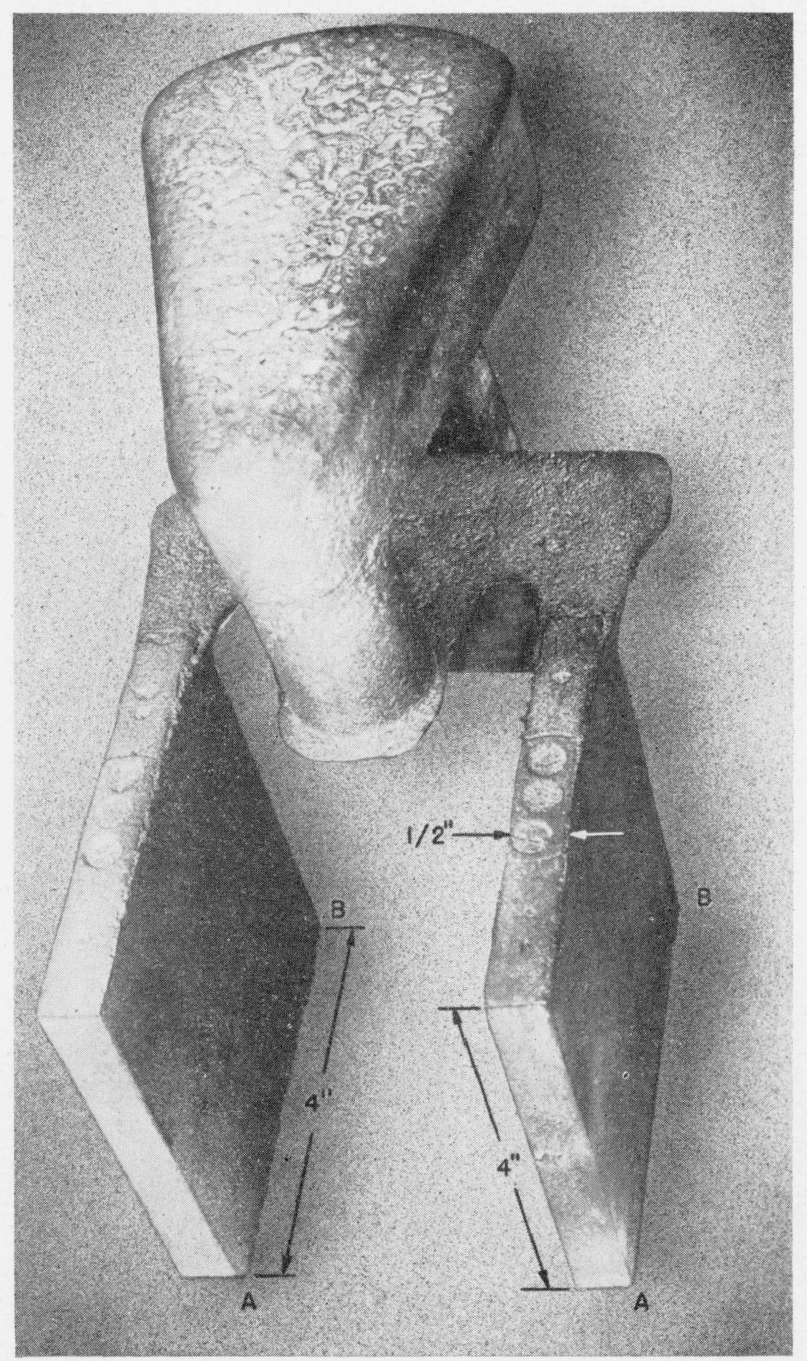

Figure 4. Chill-plate specimens cast in sand mold with bottom side $A-B$ against a heavy iron chill block. 


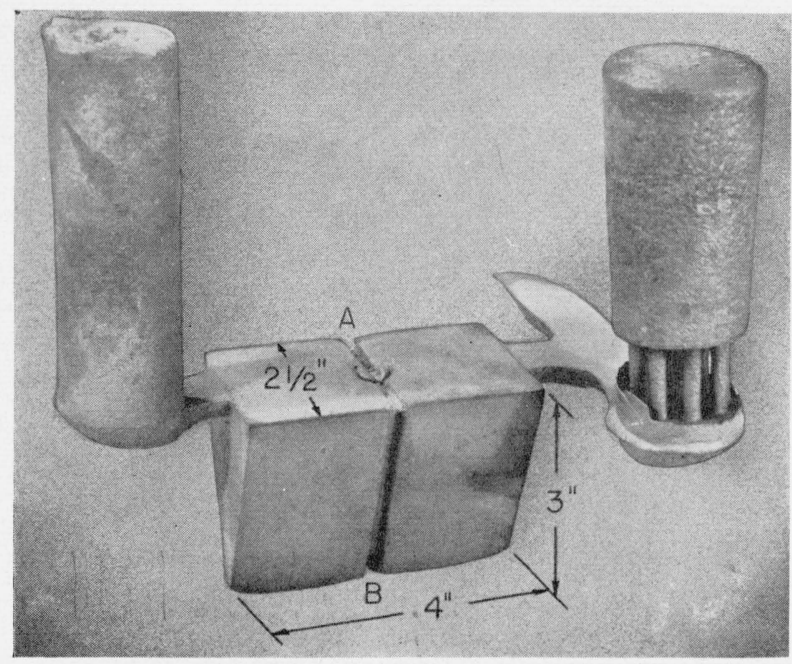

Figure 5. Chill-test wedge specimen cast in dry sand mold. A-B shows plane along which specimens were fractured.

type with a magnesia crucible and a 200-lb. lift-coil furnace with a clay-graphite crucible.

Two methods of adding ferro-boron to the iron were used. At the beginning of the investigation a small portion of the molten metal was poured into a preheated crucible to which the ferro-boron was added; the balance of the molten metal was then poured into the same crucible.

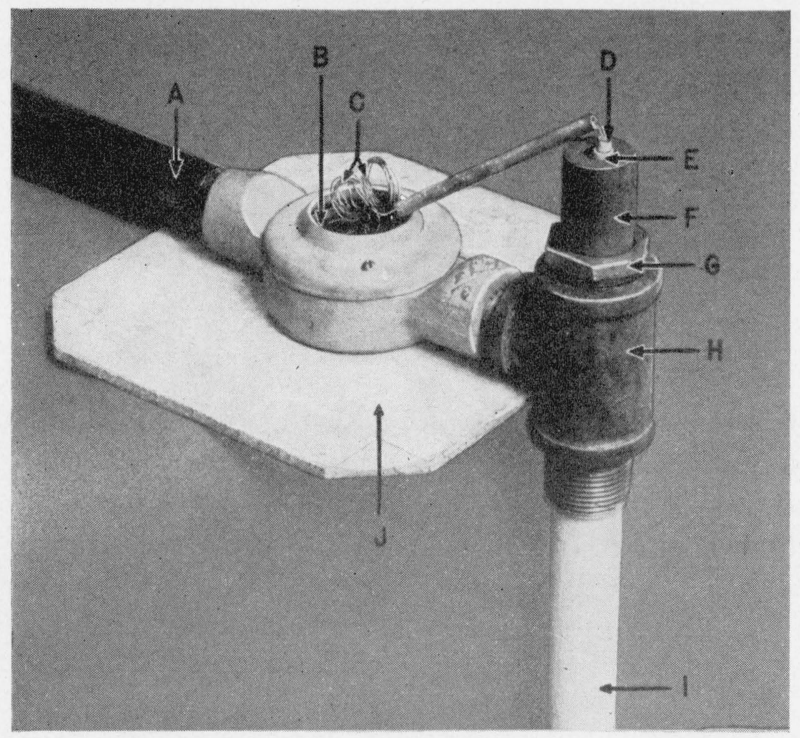

FIGURE 6. Thermocouple assembly used in measuring the temperatures of molten cast iron.

A, Thermocouple-handle enclosing extension leads; B, thermocouple junction with extension leads; $\mathrm{C}$, platinum-platinum rhodium thermocouple wires; D, two-hole porcelain insulating tube; E, porcelain tube; F, graphite tube; G, split-lock nut; H, pipe tee; I, refractory coating applied to graphite tube; J, heat-insulating plate.
Subsequently it was found that a more suitable method was to add the ferro-boron to the iron in the furnace at approximately $1,450^{\circ} \mathrm{C} .\left(2,642^{\circ} \mathrm{F}\right.$. $)$.

In order to maintain the effect of superheating as constant as possible all melts were heated to $1,500^{\circ} \mathrm{C}$. $\left(2,732^{\circ} \mathrm{F}\right.$. $)$ and poured at approximately $150^{\circ} \mathrm{C}$. $\left(270^{\circ} \mathrm{F}\right.$.) above the liquidus of the iron in each case.

Temperatures of the molten metal were measured by means of a platinum-platinum 10percent-rhodium thermocouple that was protected by a closed-end glazed porcelain tube contained in a closed-end graphite tube (fig. 6). The portion of the graphite tube in contact with the molten metal was protected by a coating of aluminumoxide cement covered with a mixture containing 95 percent of zirconium silicate and 5 percent of bentonite.

\section{Experimental Results}

\section{Effect of Boron on the Solidification Characteristics of Cast Iron}

The solidification characteristics of a number of heats of cast irons were determined by making "inverse-rate" cooling curves. The time (in seconds) required for a 0.05 -millivolt increment drop in the thermocouple potential was measured by the two-stopwatch method. During each test the crucible was covered with a lid.

It was recognized that cooling the molten metal in air and using the type of thermocouple assembly previously described (fig. 6) did not permit the precise determination of the temperature at any given instant. In order to obtain comparable results, the conditions of test were maintained as uniform as reasonably possible. Thus, in each case, $80 \mathrm{lb}$ of stock iron was melted, heated to $1,500^{\circ} \mathrm{C}$, and allowed to cool to below the solidus temperature while the data for a cooling curve were obtained. The metal was then reheated to $1,450^{\circ} \mathrm{C}$, ferro-boron added, then heated to $1,500^{\circ} \mathrm{C}$ and allowed to cool to below the solidus temperature while the data for another curve were obtained.

The cooling curves were used to evaluate the effect of boron on a comparative basis only, and since the test conditions were practically the same, the changes that occurred were attributed to differences in boron content. In one series of experiments, boron was added to four separate 


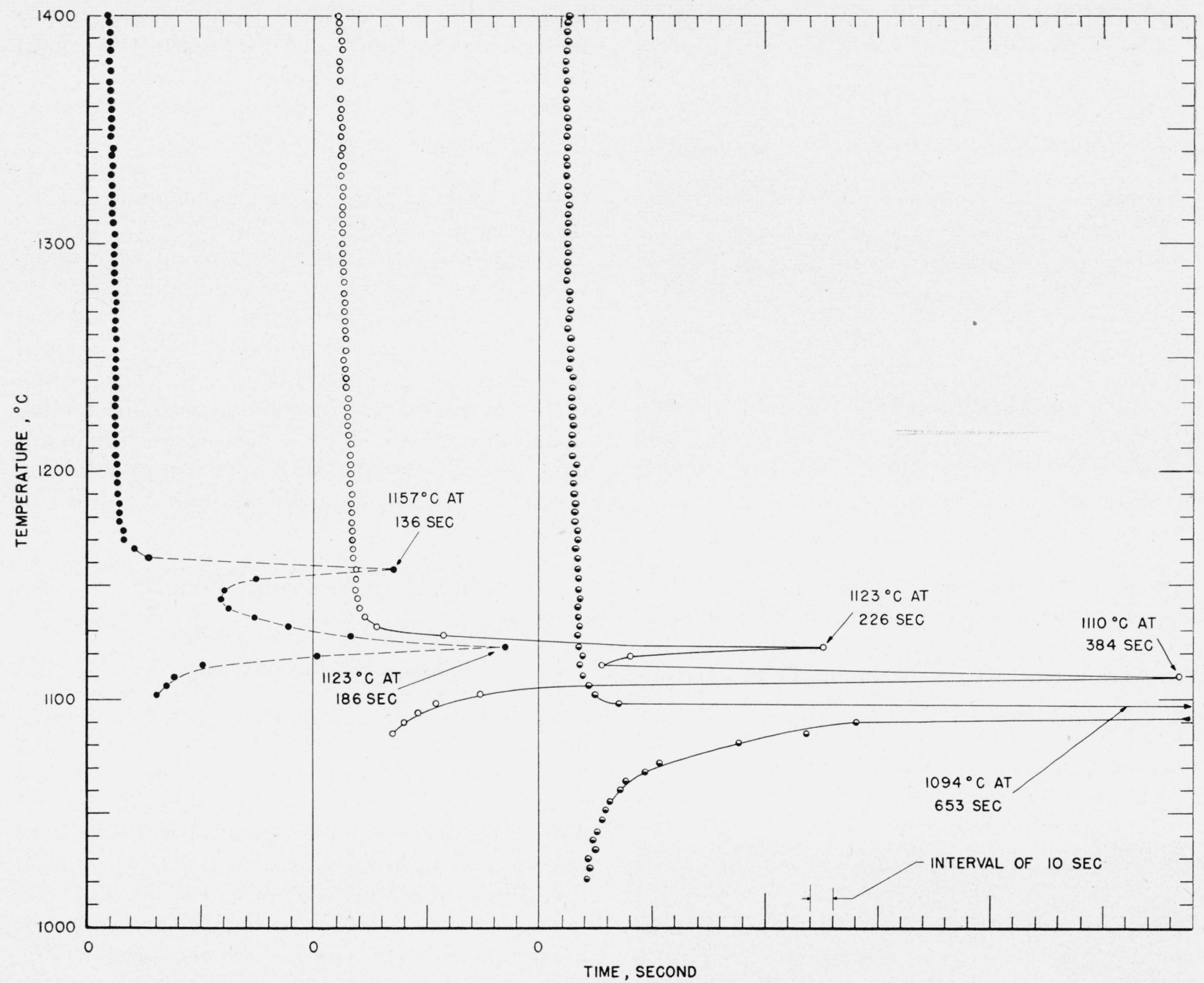

FigURE 7. "Inverse-rate" cooling curves obtained for the melts made of stock iron G-137 without and with different boron additions

๑, Heat 140 , no boron; $\bigcirc$, heat $144,0.17$ percent of boron; $\bullet$, heat $141,0.33$ percent of boron.

heats of stock iron G-137 in amounts of 0.085 , $0.17,0.29$, and 0.33 percent. A fifth heat was made with no boron addition. The cooling curves for three of the heats (table 2) are given in figure 7.

TABLE 2. Compositions of irons used for determining the cooling curves shown in figure $\%$.

\begin{tabular}{|c|c|c|c|c|c|c|c|c|}
\hline \multirow{3}{*}{ Iron } & \multicolumn{7}{|c|}{ Chemical analysis } \\
\cline { 2 - 8 } & $\begin{array}{c}\text { Heat } \\
\text { Number }\end{array}$ & $\mathrm{C}$ & $\mathrm{Si}$ & $\mathrm{Mn}$ & $\mathrm{P}$ & $\mathrm{S}$ & $\mathrm{B}$ & $\mathrm{Ti}$ \\
\hline & & $\%$ & $\%$ & $\%$ & $\%$ & $\%$ & $\%$ & $\%$ \\
$\mathrm{G}-137$ & 140 & 3.17 & 2.24 & 0.46 & 0.69 & 0.022 & 0.004 & 0.06 \\
$\mathrm{G}-137$ & 144 & 3.11 & 2.29 & .46 & .71 & .024 & .17 & $\cdots$ \\
$\mathrm{G}-137$ & 141 & 3.05 & 2.32 & .44 & .68 & .024 & .33 & $\cdots$ \\
\hline
\end{tabular}

Cooling curves for the other two heats consistently followed the trend shown by the illustrated curves: a drop in the arrest temperatures and narrowing of the temperature differences between the arrests, with an increase in boron content.

No boron was added to melt 140, for which only one cooling curve was determined. Two cooling curves were determined for each of the heats 141 and 144, one for the untreated and the other for the boron-treated iron. The cooling curves of melts 141 and 144 before treating with boron were similar to the cooling curve of heat 140 . Experiments showed that practically no change in the curves occurred due to remelting. 
On the basis of the results shown in figure 7 , it is concluded that within the limitations of the tests made the undercooling effect increased as the boron was content increased. It is noteworthy that the second recalescence reaction shown on the cooling curve of heat 144 containing 0.17 percent of boron was considerably more pronounced than that of the untreated iron, heat 140. As the boron increased, the temperature differential between the first and second recalescence reactions became smaller until the cooling curve of the borontreated heat 141 containing 0.33 percent of boron showed only one such reaction. These observations indicate that as the boron content increases in a given iron, the composition approaches the eutectic where the apparent liquidus and solidus are merged into one reaction of heat evolution. This suggests that with the increases in boron content, the amount of eutectic in these irons also increases. This observation is in agreement with Schwartz [13], who suggested that a large addition of boron $(0.88 \%)$ to white cast iron produced "an enormous shift to the left of its eutectic point".

\section{Effect of Boron on the Strength, Brinell Hardness, and Microstructure of the Transverse Cast-Iron Bars}

The cast bars, 1.2 in. in diameter, were tested on a hydraulic universal testing machine under conditions described in previous Bureau publications $[17,18]$. In every case the speed of the cross head of the testing machine was $0.12 \mathrm{in./}$ min. The relative modulus of elasticity was calculated from the slope of the secant to the loadtotal deflection curve at a load of 1,200 lb. This method avoids the tedious procedure of establishing the total, plastic, and elastic load-deflection curves by means of stepwise loading and unloading $[19,20]$.

A $3 / 4$-in.-thick disk was cut from each broken transverse-test bar adjacent to the fracture and used for Brinell-hardness determinations. Two indentations were made with a $3,000-\mathrm{kg}$ load on each disk, one at the center and the other at a point midway between the center and periphery. The hardness number of a given specimen was based on the average of the two indentations. In plain-carbon irons the amount of total carbon, silicon, and phosphorus, as well as the maximum heating and pouring temperatures, are principal factors influencing their physical properties. As the pouring temperatures were approximately constant, the significant factors to be considered in studying the effect of boron on different properties are the total carbon, silicon, and phosphorus contents.

In classifying different plain cast irons it is convenient to use the so-called "carbon equivalent value" rather than percentages of each element. There are several empirical formulas for determining this equivalent value suggested by different authors $[21,22,23]$. The most generally accepted one, $\% \mathrm{C}+0.3(\% \mathrm{Si}+\% \mathrm{P})$, is used in the present discussion. Although this formula may be somewhat less applicable to high-boron irons than to the plain irons, it is considered that it will serve for the limited classification purposes herein discussed.

For the same type of iron, with factors other than carbon equivalent remaining approximately constant, the strength and Brinell hardness will vary inversely with the carbon equivalent. Therefore, in ascertaining the effect of boron on the transverse properties and Brinell hardness of a given type of iron, only those heats possessing approximately the same carbon equivalent were considered.

Examination of the fractured transverse-test bars (table 3) revealed three classes of fractures, based on their appearance, namely, gray, white network, and mottled. The color of the gray fractures for different bars ranged from dark gray to light gray. Brinell numbers for this class varied from 140 to 220 . Brinell numbers of those having a white network were from 220 to 285 and for the mottled fractures, 295 to 427 .

Table 3 in most cases, (heats $\mathrm{E}-18 \mathrm{~B}$ and $\mathrm{E}-24$; $\mathrm{H}-8 \mathrm{~A}$ and $\mathrm{H}-8 \mathrm{~B} ; \mathrm{F}-49$ and $\mathrm{F}-57$ ) indicates that, for bars with gray fractures made from heats having approximately the same carbon equivalent, an increase in the boron content increased the Brinell hardness and moduli of rupture and elasticity. The appearance of a white network or white specks on the fractured surfaces of the test bars usually was accompanied by a drop in the transverse strength and deflection, and an increase in the modulus of elasticity and Brinell hardness. 
TABLE 3. Transverse and Brinell hardness tests

\begin{tabular}{|c|c|c|c|c|c|c|c|c|}
\hline \multirow{2}{*}{ Iron } & \multirow{2}{*}{$\begin{array}{l}\text { Heat } \\
\text { num- } \\
\text { ber }\end{array}$} & \multirow{2}{*}{ B } & \multirow{2}{*}{$\begin{array}{c}\text { Carbon } \\
\text { equivalent } \\
\mathrm{C}+0.3 \\
(\mathrm{~S}+\mathrm{P})\end{array}$} & \multicolumn{2}{|c|}{ Moduli } & \multirow{2}{*}{$\begin{array}{l}\text { Deflec- } \\
\text { tion }\end{array}$} & \multirow{2}{*}{$\begin{array}{c}\text { Brinell } \\
\text { hardness }\end{array}$} & \multirow{2}{*}{ Appearance of fracture } \\
\hline & & & & Rupture & $\underset{E_{1(8)}}{\text { Elasticity }}$ & & & \\
\hline B & $7 \mathrm{~A}$ & $\%$ & 4. 13 & $\begin{array}{c}\text { lb./in. } .^{2} \\
52.7 \times 10^{3}\end{array}$ & $\begin{array}{c}\text { lb./in. } .^{2} \\
12.98 \times 10^{6}\end{array}$ & $\begin{array}{l}\text { in. } \\
0.26\end{array}$ & 164 & Gray. \\
\hline B & $7 \mathrm{~B}$ & 0.039 & 3.97 & 62.4 & 17.80 & .19 & 221 & Light gray. \\
\hline B & 34 & .12 & 3. 98 & 45.8 & 17. 60 & .13 & 248 & White network. \\
\hline B & 111 & .31 & 4. 14 & 39.2 & 21.2 & .08 & 405 & Mottled. \\
\hline $\mathrm{C}$ & $25 \mathrm{~A}$ & .006 & 4. 23 & 57.3 & 13.3 & .24 & 197 & Gray. \\
\hline $\mathrm{C}$ & $25 \mathrm{~B}$ & .062 & 4.00 & 55.4 & 15. 2 & .19 & 202 & Do. \\
\hline $\mathrm{C}$ & 44 & .11 & 4. 31 & 43.0 & 15.4 & .13 & 218 & White network. \\
\hline $\mathrm{E}$ & $18 \mathrm{~A}$ & ...... & 4. 34 & 34.4 & 6. 27 & .27 & 140 & Dark gray. \\
\hline $\mathrm{E}$ & $18 B$ & .033 & 4. 21 & 42.5 & 8. 76 & .28 & 140 & Gray. \\
\hline $\mathrm{E}$ & 20 & .040 & 4. 17 & 48.3 & 11.43 & .26 & 170 & Do. \\
\hline $\mathrm{E}$ & 24 & .061 & 4. 22 & 48.1 & 11. 64 & .24 & 175 & Do. \\
\hline $\mathrm{E}$ & 33 & .11 & 4.02 & 45.4 & 23.90 & .09 & 295 & Mottled. \\
\hline $\mathrm{G}$ & $11 \mathrm{~A}$ & (n.... & 4. 34 & 47.8 & 11.54 & .22 & 156 & Gray. \\
\hline G & 140 & .004 & 4.04 & 56.8 & 13.8 & .21 & 215 & Light gray. \\
\hline G & $11 \mathrm{~B}$ & .042 & 4. 23 & 54.1 & 12.96 & .23 & 197 & Do. \\
\hline G & 143 & .085 & 4.05 & 52.7 & 16.6 & .16 & 225 & Do. \\
\hline G & 144 & .17 & 4. 01 & 46. 2 & 17.1 & .13 & 267 & White network. \\
\hline G & 145 & .29 & 3.85 & 32.2 & 21.4 & .07 & 341 & Mottled. \\
\hline G & 141 & .33 & 3.95 & 17.0 & n...... & - n & 427 & Mottled almost white. \\
\hline $\mathrm{H}$ & $8 \mathrm{~A}$ & …... & 4.40 & 46. 6 & 10.41 & .24 & 167 & Dark gray. \\
\hline $\mathrm{H}$ & $8 \mathrm{~B}$ & .038 & 4. 40 & 51.4 & 12.48 & .23 & 183 & Gray. \\
\hline $\mathrm{H}$ & 83 & .16 & 4. 29 & 33.0 & 16.6 & .10 & 271 & White network. \\
\hline $\mathrm{F}$ & 48 & .003 & 4.54 & 41.0 & 9.9 & .21 & 157 & Dark gray. \\
\hline $\mathrm{F}$ & 49 & .003 & 4.44 & 42.9 & 9.6 & .24 & 157 & Do. \\
\hline $\mathrm{F}$ & 57 & .16 & 4.41 & 45.9 & 13.6 & .17 & 199 & Light gray. \\
\hline
\end{tabular}

\section{Microstructural Features}

Microscopic examinations were conducted on specimens cut from the transverse bars and the chill-test plates. Typical structures of the transverse test bars cast from different heats prepared from the same basic iron but containing various amounts of boron are illustrated in figures 8 to 12 . Figure 8 shows the structure of untreated iron, whereas figures 9 to 12 are representative of the irons containing $0.085,0.17,0.29$, and 0.33 percent of boron, respectively. It may be noted (table 3 ) that the fractures of the bars containing more than 0.29 percent of boron were either mottled or practically white.

As previously stated, boron produced an undercooling effect, but contrary to expectations, no undercooled fine graphite structure, such as described by Norbury [24], was observed in the microstructures. As the boron content increased, the amount of graphite decreased, and the graphite flakes were reduced in size. The structure of the irons without boron addition consisted essentially of pearlite and ferrite (fig. 8, B), whereas those of the irons containing 0.085 and 0.17 percent of boron consisted principally of pearlite and carbides (figs. 9, B, and 10, B). With a further increase in boron $(0.29 \%)$ the structure consisted of islands of pearlite and cementite (fig. 11, B). Some of these islands contained pearlite surrounded by an envelope, whereas others showed only traces of pearlite. As the structure of the envelopes surrounding the islands of pearlite is practically undefined at the magnifications used in this work, they will be referred to as "structureless". When the boron content was increased to and above 0.33 percent, most of these islands showed only faint or no structure, and in the present discussion will be referred to as "structureless" (fig. 12, B).

Allen [25] showed structureless envelopes surrounding pearlitic areas in chilled cast iron, and he concluded that they were austenite. As the authors have suggested, high-boron contents (approximately $0.3 \%$ and higher) produce a considerable shift of the eutectic point of the 
iron-carbon constitution diagram to the left, and the microstructure of such irons at their solidification temperatures may be expected to consist of the austenite-cementite eutectic (Ledeburite), plus either saturated austenite (gamma iron with carbon) or hypereutectic (primary) cementite, depending on whether the iron composition is hypoeutectic or hypereutectic. With further cooling, the austenite usually transforms to pearlite, so that the white iron structure at room temperature consists of pearlite, cementite, and possibly some untransformed austenite.
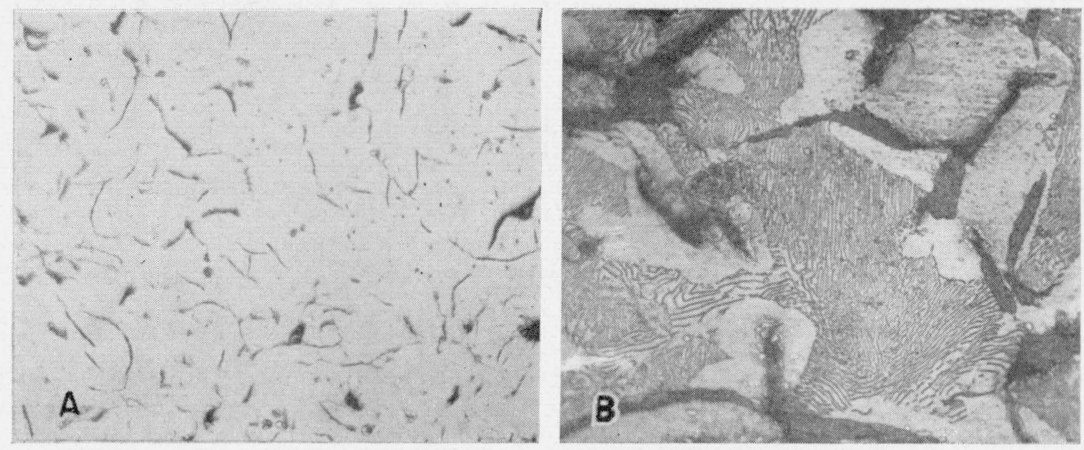

Figure 8. Typical mierostructure of transverse test bars of plain cast iron.

Total carbon, 3.17 percent; graphitic carbon, 2.68 percent; combined carbon, 0.49 percent; Si, 2.24 percent; P, 0.69 percent; Mn, 0.46 percent; $\mathrm{S}, 0.022$ percent; $\mathrm{B}, 0.004$ percent; modulus of rupture $=56,800 \mathrm{lb} / \mathrm{in}^{2} ; E_{1(s)}=13.8 \times 10^{6} \mathrm{lb} / \mathrm{in} .{ }^{2} ;$ Brinell hardness number $=215$; basis metal is stock iron $\mathrm{G}-137$. A, Unetched, $\times 100$; $\mathrm{B}$, etched with 1 percent of nital, $\times 500$.
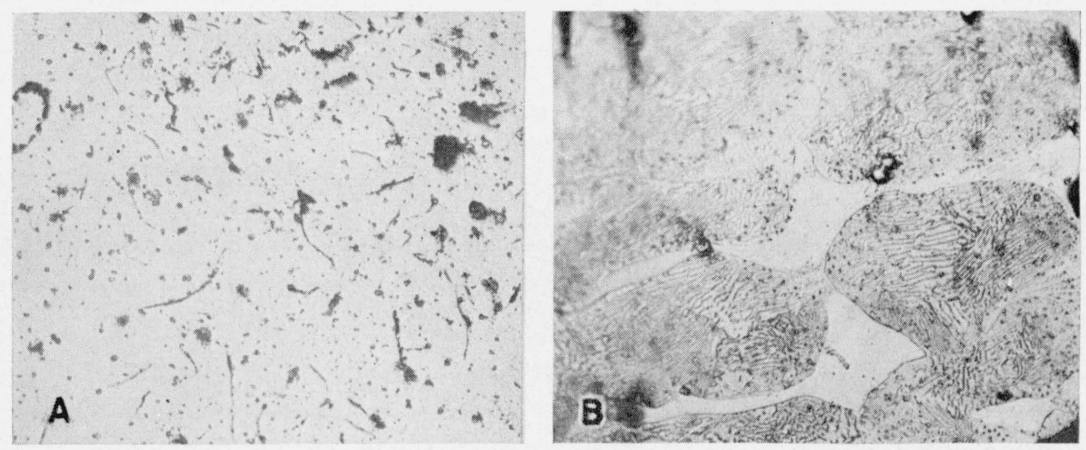

Figure 9. Typical microstructure of transverse test bars of boron-treated cast iron.

Total carbon, 3.15 percent; graphitic carbon, 2.37 percent; combined carbon, 0.78 percent; $\mathrm{Si}, 2.30$ percent; $\mathrm{P}, 0.71$ percent; $\mathrm{Mn}, 0.47$ percent; $\mathrm{S}, 0.024$ percent . B, 0.085 percent; modulus of rupture $=52,700 \mathrm{lb} / \mathrm{in}^{2} ; E_{1(s)}=16.6 \times 10^{6} \mathrm{lb} / \mathrm{in} .{ }^{2}$; Brinell hardness number $=225$; basis metal is stock iron G-137. A, Unetched, $\times 100$; $B$, etched with 1 percent of nital, $\times 500$.
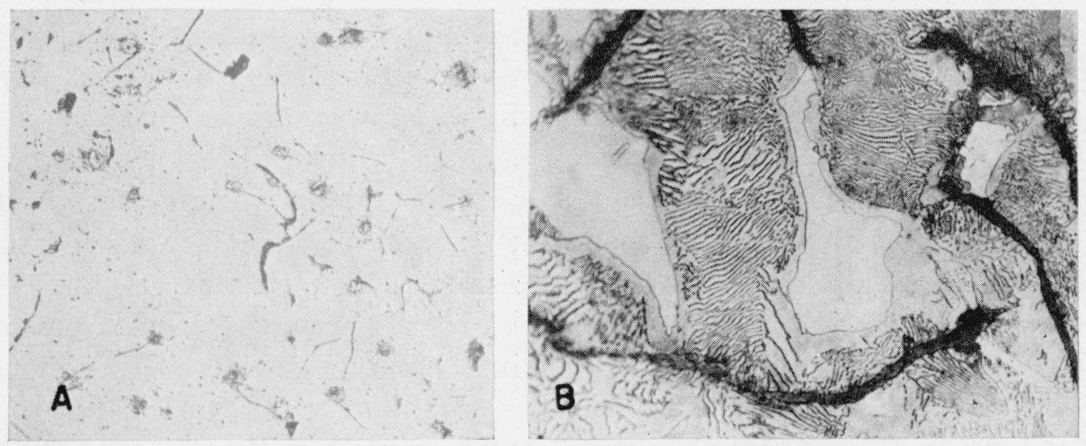

FIGURE 10. Typical microstructure of transverse test bars of boron-treated cast iron.

Total carbon, 3.11 percent; graphitic carbon, 1.98 percent; combined carbon, 1.13 percent; Si, 2.29 percent; $\mathrm{P}, 0.71$ percent; $\mathrm{Mn}, 0.46$ percent; $\mathrm{S}, 0.024$ percent; $\mathrm{B}, 0.17$ percent; modulus of rupture $=46,200 \mathrm{lb} / \mathrm{in} .{ }^{2} ; E_{1(s)}=17.1 \times 10^{6} \mathrm{lb} /$ in..$^{2}$; Brinell hardness number $=267$; basis metal is stock iron $\mathrm{G}-137$. A, Unetched, $\times 100$; $\mathrm{B}$, etched with 1 percent of nital, $\times 500$. 

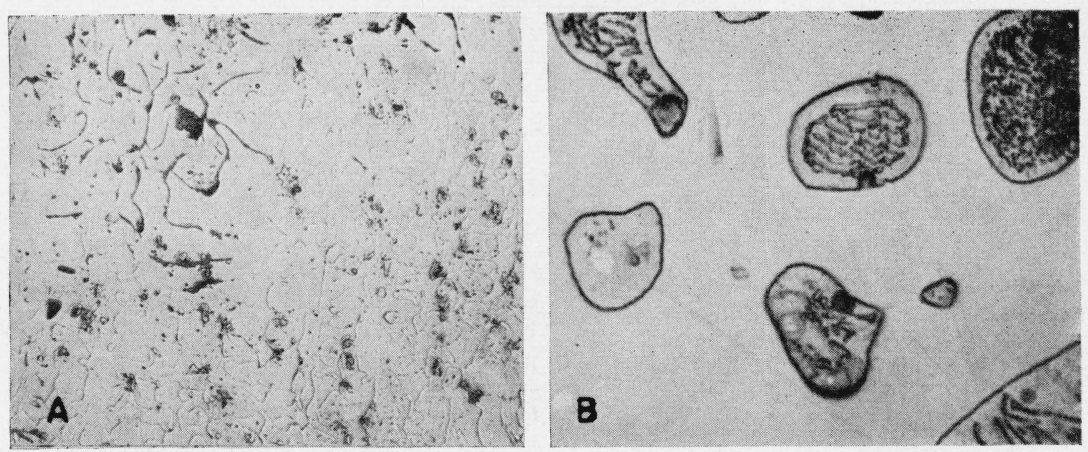

FiguRE 11. Typical microstructure of transverse test bars of boron-treated cast iron.

Total carbon, 2.98 percent; graphitic carbon, 0.72 percent; combined carbon, 2.26 percent; Si, 2.22 percent; P, 0.69 percent; Mn, 0.40 percent; S, 0.020 percent; B, 0.29 percent; modulus of rupture $=32,270 \mathrm{lb} / \mathrm{in} .{ }^{2} ; E_{1(s)}=21.4 \times 10^{6} \mathrm{lb} / \mathrm{in} .{ }^{2} ;$ Brinell hardness number $=341$; basis metal is stock iron G-137. A, Unetched, $\times 100$; $\mathrm{B}$, etched with 1 percent of nital, $\times 1,500$.

A number of tests were conducted in the attempt to ascertain whether boron, when present in sufficient quantity in cast iron, may suppress the transformation of austenite at room temperatures and produce envelopes of austenite, such as Allen reported for plain cast irons. At first, Knoop microhardness tests, using a 100-g load, were made to determine the relative hardness of the constituents. For the same purpose, the Bierbaum scratch hardness tester was used. The latter instrument produces a scratch by drawing a hard stylus under constant load across a polished surface of the specimen. In this particular instance the load was $1.5 \mathrm{~g}$. The scratch produced was very fine and could be detected only under the microscope at high magnification.

A number of Knoop microhardness determinations were made, under similar conditions, on a specimen containing 0.33 percent of boron. The indentations made on the structureless islands were much larger than those made on the cementite (fig. 13). As variations in the microhardness numbers may be caused by such factors as difference in crystal orientation; differences in the thickness of the microconstituent at the site of the impression permitting possible penetration of the indenter into a softer or harder underlying structure; and the appearance of cracks in the specimen around the indentation [26, 27], these results are not considered absolute values for the hardness. However they do indicate the relative hardness of the constituents, and it may be concluded that the island constituent is softer than the cementite matrix surrounding it. Another difficulty lies in confining the identation solely to the area or constituent under investigation, particularly if these areas are very small. The Knoop microhardness test results were substantiated by the scratch-hardness test values. Examination at high magnification revealed that the narrow portions of a scratch (indicating higher hardness) occurred on the cementite areas, whereas its wider parts (lower hardness) occurred in the pearlitic and structureless-island areas.

The second series of tests consisted in quenching specimens, similar to those tested for hardness, in liquid air to ascertain whether transformational changes would occur in the structureless islands. The first specimen was examined microscopically at 1,500 diameters and a ring scratched around a suitable area containing islands of the constituent presumed to be austenite. The specimen was then immersed in liquid air for $1 / 2 \mathrm{hr}$., removed from the bath, allowed to reach room temperature, and reexamined microscopically. Another specimen taken from a bar poured from the same melt as the first specimen and having the same structure was given a slightly different treatment. This specimen was immersed in liquid air for $3 \mathrm{~min}$, removed from the bath for $3 \mathrm{~min}$; then immersed for $5 \mathrm{~min}$, removed for $3 \mathrm{~min}$; then immersed again for $1 / 2 \mathrm{hr}$. This procedure was followed to set up stresses within the specimen to facilitate the start of austenite transformation. A third similar specimen was immersed in the liquid-air bath for $1 \mathrm{hr}$ and $10 \mathrm{~min}$. In no case was a change in the structure of the specimens observed.

In the next series of tests two additional specimens were taken from the same bars (melt 141) from which specimens were cut for hardness and liquid air quenching tests. Both specimens were $1.2 \mathrm{in}$. in diameter. One of them was $1 \frac{1}{4}$ in. long, 

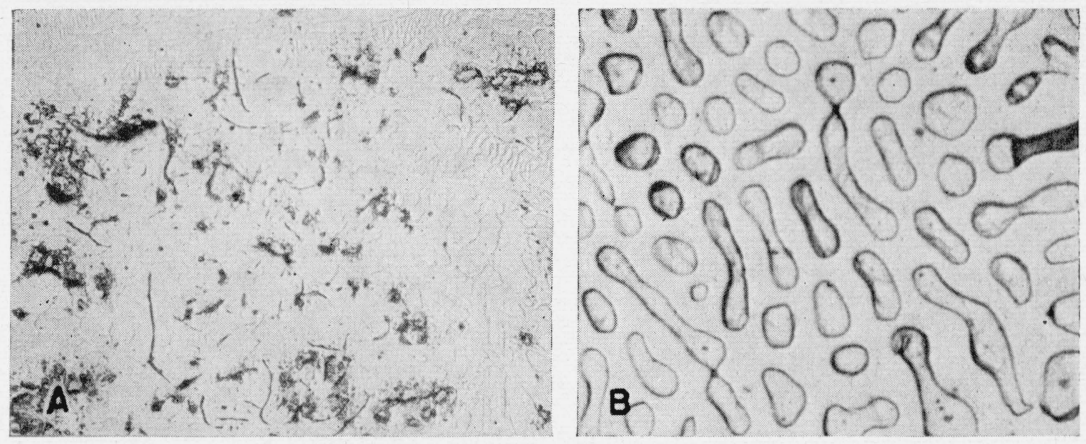

FIGURE 12. Typical microstructure of transverse test bars of boron-treated cast iron.

Total carben, 3.05 percent; graphitic carbon, 0.58 percent; combined carbon, 2.47 percent; Si, 2.32 percent; P, 0.68 percent; Mn, 0.44 percent; S, 0.024 percent; $\mathrm{B}, 0.33$ percent; modulus of rupture $=17,000 \mathrm{lb} /$ in. ${ }^{2}$; Brinell hardness number $=427$; basis metal is stock iron $\mathrm{G}-137$. A, Unetched, $\times 100$. B, etched with 1 percent of nital, $\times 1,500$.

the other $3 / 4$ in. The $3 / 4$-in. specimen was polished, etched, and examined under the microscope. The structure was similar to that shown in figure $12 \mathrm{~B}, \mathrm{~F} . \mathrm{G}, \mathrm{H}$. The $1 \frac{11 / 4}{4}$ in. specimen was subjected to a magnetic test, and the magnetic saturation value, $B_{s}$, was determined to be approximately 15.3 kilogausses. Both specimens were then annealed for $6 \mathrm{hr}$ at $680^{\circ} \mathrm{C}$ in an electric air-muffle furnace. The $1 \frac{1}{4}$-in. specimen was again subjected to the magnetic test, which showed that no significant change in the magneticsaturation value, $B_{s}$, had been caused by annealing. The annealed $3 / 4$-in. specimen was given a light polish to remove the thin oxide film from the surface, etched, and examined microscopically. A comparison of its structure (fig. 14) with that before annealing (fig. 12B) shows that the structureless islands were unaffected by the annealing treatment. Most of the pearlitic areas had spheroidized, and some of the islands that previously contained pearlite at their centers showed only a few globules of coalesced cementite.

These results suggest that the structureless components of the boron-treated irons are not austenite. Further, the hardness tests indicated that these constituents are not cementite. These considerations lead the authors to suggest that the structureless envelopes surrounding the pearlite areas are ferrite; the structureless islands consist of very fine pearlite unresolved by the light microscope. It is probable that we are dealing here with complex ferrite and pearlite.

Previous investigators have suggested that the presence of the complex constituents ferrite ( $\mathrm{Fe} \mathrm{B}$ ), pearlite $\left(\mathrm{Fe} \mathrm{B}-\mathrm{Fe}_{3} \mathrm{CFe}_{2} \mathrm{~B}\right)$, and cementite $\left(\mathrm{Fe}_{3} \mathrm{C}\right.$ $\left.\mathrm{Fe}_{2} \mathrm{~B}\right)$ in the boron-treated irons is very probable.

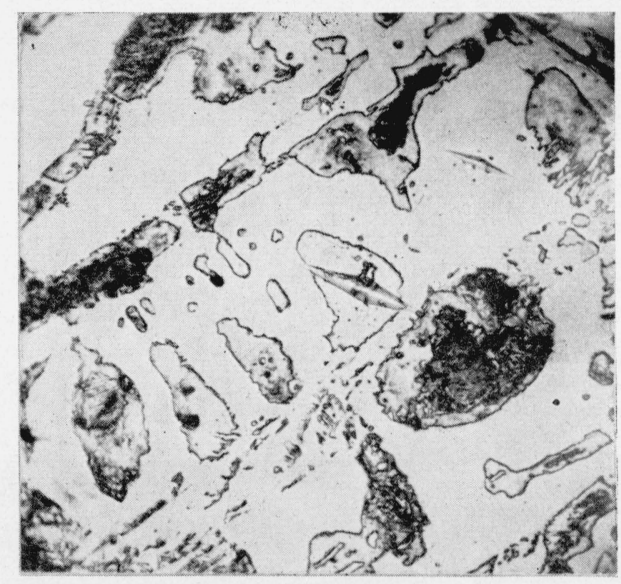

Figure 13. Micrograph showing Knoop hardness indentations on different structural components of transverse test bar cast from stock iron $G-13 \%$.

Total carbon, 3.05 percent; Mn, 0.44 percent; $\mathrm{P}, 0.68$ percent; $\mathrm{S}, 0.024$ percent; $\mathrm{Si}, 2.32$ percent; $\mathrm{B}, 0.33$ percent. Etched with 1 percent of nital, $\times 500$.

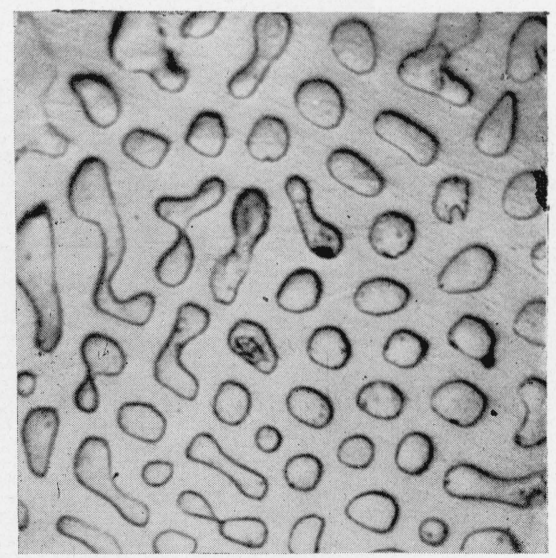

FIGURE 14. Microstructure of transverse test bar prepared from stock iron $G-13 \%$, heat 141 (same bar was used for specimens whose structures are shown in fig. 12).

Specimen annealed at $680^{\circ} \mathrm{C}$ for $6 \mathrm{hr}$. Etched with 1 percent of nital, $\times 1,500$. 
It is also likely that the behavior of these complex constituents is quite different from that of the constituents of plain cast iron.

The authors, in their microscopic analysis, using different etching reagents, failed to detect any difference in appearance between the carbides of the boron-treated and untreated irons. The authors also failed to detect the envelopes of insoluble constituent described by Tisdale [28], as well as the boron constituent observed by Grange and Garvey [29] in boron-treated steels, appearing as a single or multiple row of dots.

\section{Effect of Boron on the Chilling Properties,} Hardness, and Microstructure of the Cast Iron Chill Test Specimens

The depth of chill determined on the plate and wedge specimens, (figs. 4 and 5) was taken as a criterion of the susceptibility to chill of the different irons. To measure the depth of chill the plates (fig. 4) were broken at the middle, perpendicular to the chilled side; the wedge specimens were broken along the full length of the groove $\mathrm{AB}$ (fig. 5). Figures 15 and 16 show the whitening effect of boron contents on the fracture sections of chill plates and chill wedges cast from different melts, each of a different boron content and made of the specially prepared stock iron of uniform composition (table 1, stock iron D-107). All these castings were made under similar melting and pouring conditions. There was a pronounced increase in the depth of chill with an increase in the boron content. An increase in the boron content is accompanied by an increase in the white network of the gray portions of the castings (figs. 15 and 16). The chilled areas of the plates usually consisted of two zones, a completely white zone, so-called clear chill, and a partly chilled or mottled zone. For irons containing large amounts of boron, 0.32 percent and higher (figs. 15 and 16), the chill plates proved inadequate for measuring the depth of chill. The fractures of plates containing 0.32 and 0.35 percent of boron are white and mottled (fig. 15, F and G), whereas those containing 0.37 and 0.48 percent of boron are wholly white (fig. 15, $\mathrm{H}$ and $\mathrm{J}$ ). Black areas on the photographs (fig. $15, \mathrm{H}$ and $J$ ) are shadows cast by projecting portions of the fractured edge.

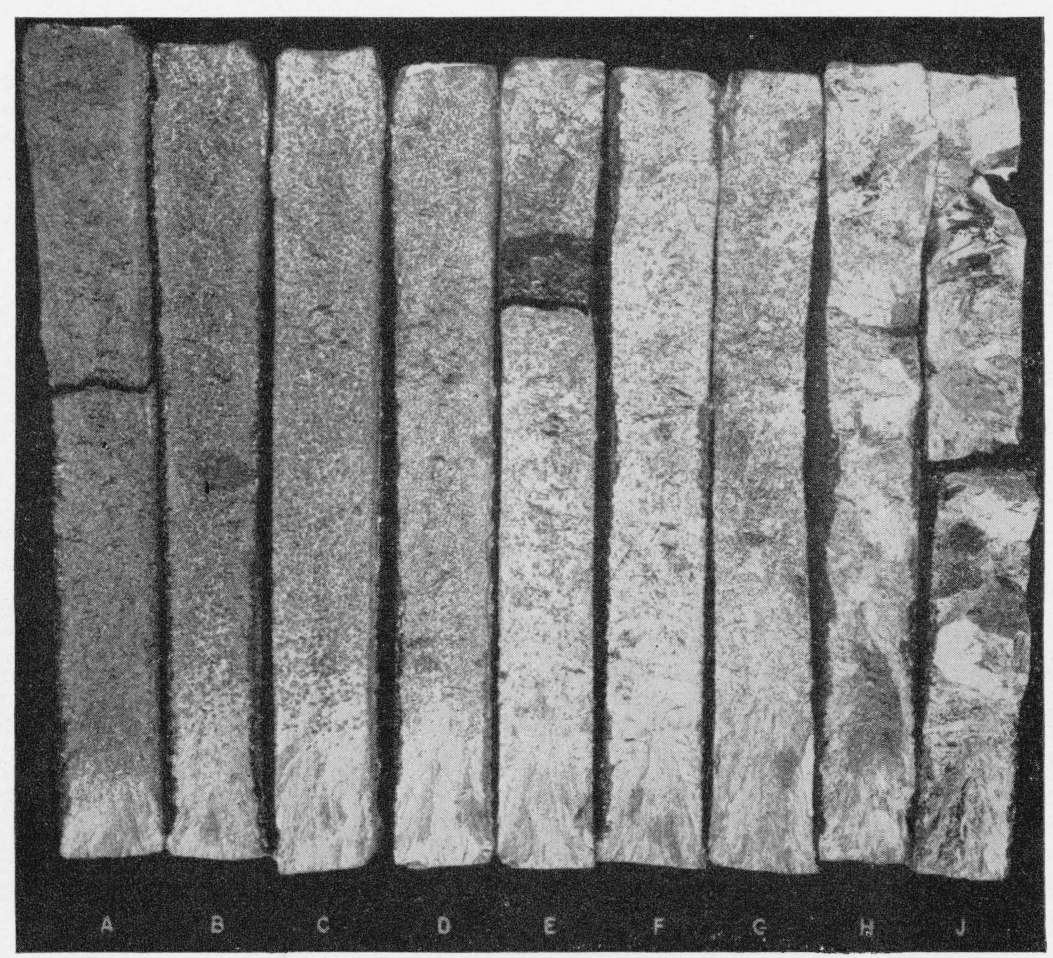

Figure 15. Chill-plate fraclures.

Stock iron D-107. Boron contents: A, 0.002 percent; B, 0.055 percent; C, 0.06 percent; D, 0.16 percent; E, 0.20 percent; F, 0.32 percent; G, 0.35 percent; H, 0.37 percent; J, 0.48 percent. 


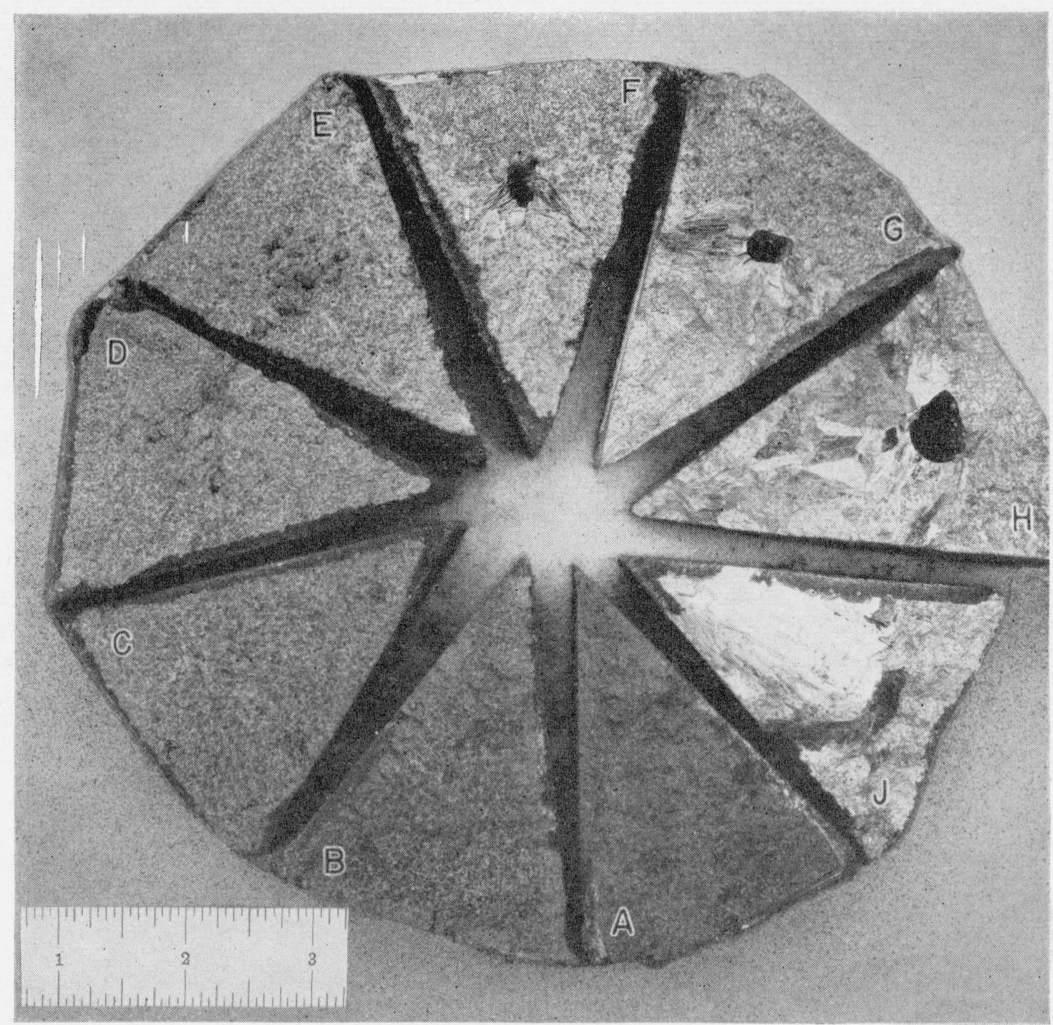

Figure 16. Chill-wedge fractures.

Stock iron D-107. Boron contents: A, 0.002 percent; B, 0.055 percent; C, 0.06 percent; D, 0.16 percent; E, 0.20 percent; F, 0.32 percent; G, 0.35 percent; H, 0.37 percent; $\mathrm{J}, 0.48$ percent.

The black areas shown in figure $16, \mathrm{D}, \mathrm{E}, \mathrm{F}, \mathrm{G}$, $\mathrm{H}$, and $\mathrm{J}$, are shrinkage cavities. In the wedges containing $0.35,0.37$, and 0.48 percent of boron, the mottled zones were absent, and the white portion of the wedge, containing 0.48 percent of boron (fig. 16, J), consisted of a massive columnar structure, whereas the white fractures of the other two irons (fig. 16, $\mathrm{G}$ and $\mathrm{H}$ ) showed randomly oriented crystals. The depths of chill of the plate and wedge specimens are given in table 4 . The depths of chill of the plates are expressed in percentage of their height (4 in.). The depths of chill of the wedges are given in inches.

Vickers hardness determinations were made on the white portion (clear chill) of the chill plate specimens, by using a $50-\mathrm{kg}$ load. The results of the Vickers over-all hardness values are presented in table 4 for various heats of stock iron D-107. In general, an increase in the Vickers numbers accompanied an increase in boron content. The relationship was particularly significant for the irons containing 0.35 to 0.48 percent of boron. This correlation existed only among specimens made from the same basic irons. It is noteworthy that the Vickers hardness number of the chill plate containing 0.48 percent of boron was approximately 720

TABLE 4. Influence of boron content on the depth of chill and hardness of castings

All heats were made from basic stock iron D-107 a

\begin{tabular}{|c|c|c|c|c|c|c|c|c|}
\hline \multirow{3}{*}{$\begin{array}{l}\text { Heat } \\
\text { num- } \\
\text { ber }\end{array}$} & \multirow{3}{*}{$\begin{array}{c}\text { Boron } \\
\text { con- } \\
\text { tent }\end{array}$} & \multicolumn{6}{|c|}{ Depth of chill } & \multirow{3}{*}{$\begin{array}{l}\text { Hardness } \\
\text { tests made } \\
\text { on white } \\
\text { portions } \\
\text { of chill } \\
\text { plates } \\
\text { Vickers } \\
\text { over-all } \\
\text { hardness } \\
\text { average } \\
\text { values }\end{array}$} \\
\hline & & \multicolumn{3}{|c|}{ Chill plates } & \multicolumn{3}{|c|}{ Chill wedges } & \\
\hline & & $\begin{array}{l}\text { Clear } \\
\text { chill }\end{array}$ & $\begin{array}{l}\text { Mot- } \\
\text { tled } \\
\text { zone }\end{array}$ & $\begin{array}{l}\text { Total } \\
\text { chill }\end{array}$ & $\begin{array}{l}\text { Clear } \\
\text { chiii }\end{array}$ & $\begin{array}{l}\text { Mot- } \\
\text { tled } \\
\text { zone }\end{array}$ & $\begin{array}{l}\text { Total } \\
\text { chill }\end{array}$ & \\
\hline 108 & $\begin{array}{c}\% \\
0.002\end{array}$ & $\begin{array}{l}\% \\
9.5\end{array}$ & $\begin{array}{l}\% \\
4.0\end{array}$ & $\begin{array}{l}\% \\
13.5\end{array}$ & $\begin{array}{l}\text { in. } \\
0\end{array}$ & $\begin{array}{l}\text { in. } \\
0\end{array}$ & $\begin{array}{l}\text { in. } \\
0\end{array}$ & 560 \\
\hline 118 & .055 & 17.5 & 7.5 & 25.0 & 0 & 0 & 0 & \\
\hline 115 & .06 & 17.5 & 7. 5 & 25.0 & 0 & 0 & 0 & 605 \\
\hline 114 & .16 & 21.0 & 11.5 & 32.5 & 0 & 0 & 0 & 615 \\
\hline 113 & .20 & 24.0 & 76.0 & 100 & 0 & 0.60 & 0.60 & 610 \\
\hline 112 & .32 & 30.0 & 70 & 100 & 1.0 & 1. 50 & 2. 50 & 620 \\
\hline 109 & .35 & 31.0 & 69 & 100 & 2. 40 & 0 & 2.40 & 630 \\
\hline 116 & .37 & 100 & 0 & 100 & 2. 50 & 0 & 2. 50 & 685 \\
\hline 117 & .48 & 100 & 0 & 100 & 2. 25 & 0 & 2. 25 & 720 \\
\hline
\end{tabular}

a Figures 15 and 16 show the fractured surfaces of the chill test specimens (plates and wedges) listed in this table. 

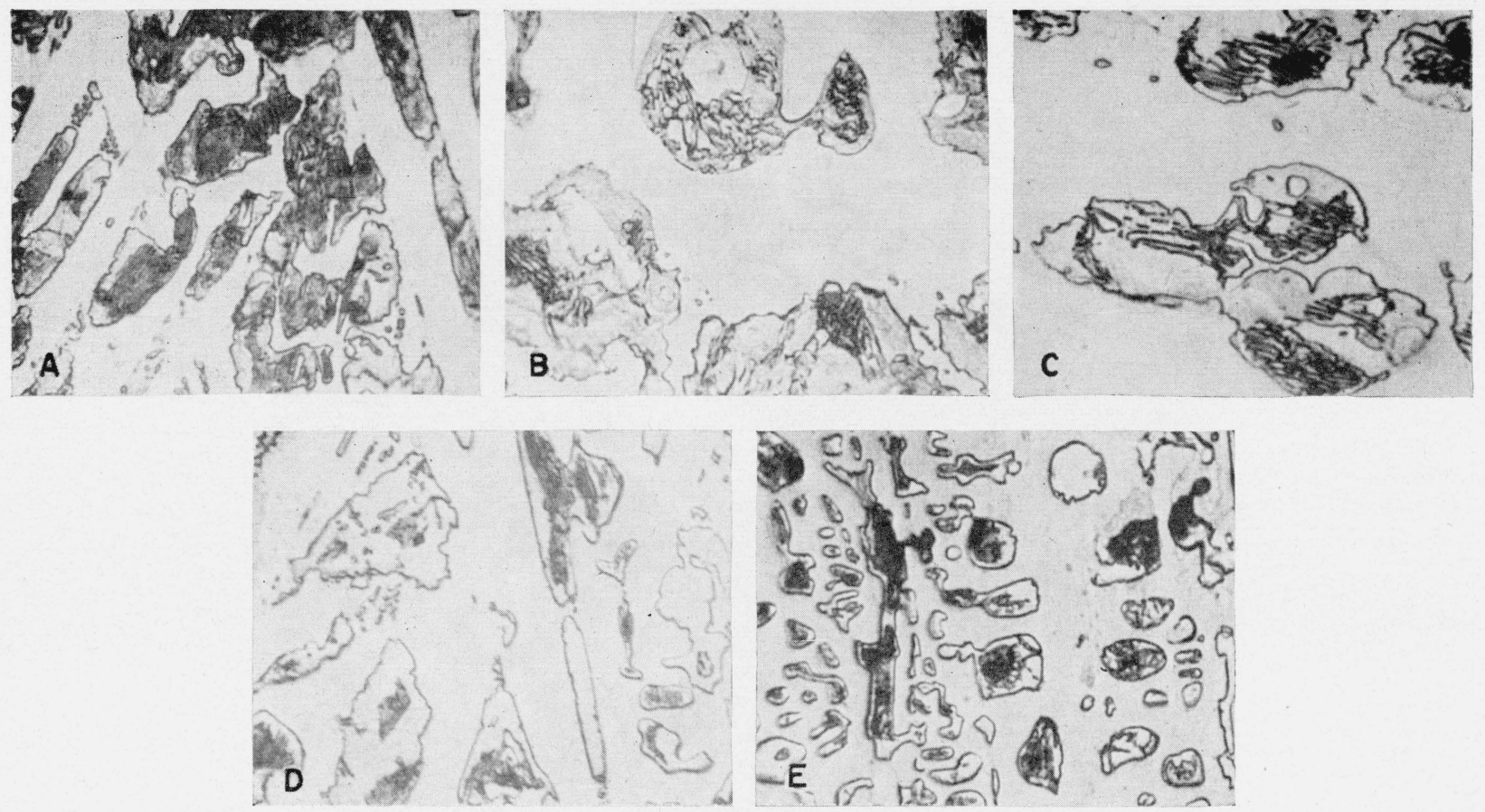

FIGURE 17. Microstructures of chill plates prepared from stock iron G-13\%.

Etched with 1 percent of nital, $\times 1,500$. A, Total carbon, 3.17 percent; Si, 2.24 percent; $\mathrm{P}, 0.69$ percent; $\mathrm{Mn}, 0.46$ percent; $\mathrm{S}, 0.022$ percent. B, 0.004 percent. B, Total carbon, 3.15 percent; $\mathrm{Si}, 2.30$ percent; $\mathrm{P}, 0.71$ percent; $\mathrm{Mn}, 0.47$ percent; $\mathrm{S}, 0.024$ percent. B, 0.085 percent. $\mathrm{C}$, Total carbon, 3.11 percent; Si, 2.29 percent; P, 0.71 percent; Mn, 0.46 percent; S, 0.024 percent; B, 0.17 percent. D, Total carbon, 2.98 percent; Si, 2.22 percent; P, 0.69 percent; Mn, 0.40 percent; S, 0.020 percent; B, 0.29 percent. E, Total carbon, 3.05 percent; Si, 2.32 percent; $\mathrm{P}, 0.68$ percent; $\mathrm{Mn}, 0.44$ percent; $\mathrm{S}, 0.024$ percent; $\mathrm{B}, 0.33$ percent.

(equivalent to approximately 620 to 650 Brinell), which is considerably higher than that value for ordinary white iron whose Brinell numbers range from 320 to 530 .

The microstructures of the chilled portions of chill plates containing different amounts of boron are shown in figure 17 . The characteristic structureless constituent, in some cases cored with pearlite, previously discussed (figs. 9 to 12), were also observed in these chilled areas.

\section{Summary}

A study was made to ascertain the effects of boron additions on the microstructural features and mechanical properties of plain gray cast iron. Transverse-test bars and chill specimens containing up to approximately 0.5 percent of boron were cast. The results and conclusions are as follows:

1. Boron-containing cast iron suffered no significant boron losses during one or more remeltings.

2. Of the elements in cast iron, only carbon appeared to show a consistent decrease with an increase in boron.
3. Cooling curves, obtained during solidification of melts, indicated that increasing amounts of boron produced progressively increased undercooling effects and lessened the temperature difference between the apparent liquidus and solidus, thus indicating an approach to the eutectic composition.

4. For bars showing a gray fracture after boron addition, there was a slight increase in the moduli of rupture and elasticity. The appearance of a white network or white specks on the fractured surface usually was accompanied by a drop in the transverse strength and deformation, and an increase in the modulus of elasticity.

5. The susceptibility of different irons to chill increased with an increase of the boron content.

6. Brinell-hardness determinations made on transverse-test bars, in general, showed an increase in hardness with an increase in boron content. Vickers hardness determinations on the white portions of the chill plates also showed, in most cases, an increase in hardness with an increase in boron content.

7. As the boron content of the irons increased, 
the amount and size of graphite flakes decreased; simultaneously there was an increase in the amount of free carbide. With boron contents of 0.29 percent or more, the structure of the irons consisted essentially of a matrix of cementite containing islands of pearlite and islands with a practically unresolved structure. The pearlite areas appeared to be surrounded by a structureless envelope, which is believed to be ferrite. The structureless islands probably are very fine pearlite, which could not be resolved with the light microscope.

8. No microstructural differences in the appearance of carbides in boron-treated and untreated irons were detected, although the cementite of boron-containing iron is thought to be of a complex nature.

Grateful acknowledgment is made to Richard H. Harwell, Richard C. Rohan, and Mrs. Irene C. Minor for assistance in this investigation.

Chemical analyses required in this study were made by the Analytical Chemistry Section of the Chemistry Division, and all magnetic measurements by the Section on Magnetic Measurements of the Electricity and Optics Division.

\section{References}

[1] L. A. Carapella, Fundamental alloying nature of magnesium, Metal Progress 48, 297 (1945).

[2] N. Tschischewsky and A. Herdt, Iron-boron and ironcarbon alloys, Iron Age 90, 396 (1916). (Paper taken from the J. Russ. Met. Soc., 1915.)

[3] Metal Handbook, 1948 ed. (Am. Soc. Metals, Cleveland, Ohio).

[4] M. Hansen, Der Aufbau der Zweistofflegierungen (J. Springer, Berlin, 1936).

[5] G. Hannesen, Über Borstähle, Z. anorg. Chem. 89, 257 (1914).

[6] F. Wever and M. Müller, Ueber die Zweistoffsysteme Eisen-Bor und Eisen-Beryllium, miteinem Beitrag zur Kenntnis des Zweistoffsystems Eisen-Aluminium, Mitt. Kaiser-Wilhelm-Inst. Eisenforsch. Düsseldorf 11; 193 (1929).

[7] R. Vogel and G. Tamman, Über das ternäre System Eisen-Bor-Kohlenstoff, Z. Anorg. Allgem. Chemie 123, 225 (1922).

[8] G. K. Burgess and R. W. Woodward, Manufacture and properties of steel plates containing zirconium and other elements, Tech. Pap. BS 16, 123 (1922) T207.

[9] R. Walter, U. S. Patent 1,519,388 (Dec. 16, 1924).

[10] H. A. Schwartz, Boron as an accelerator of malleable annealing, Foundry 72,129 (1944).
[11] N. F. Tisdale, Boron in malleable iron, Foundry $\mathbf{7 3 ,}$ 107 (1945).

[12] G. Joly, Influence of chromium on graphitization of white cast iron, Am. Foundryman 14, 60 (1948).

[13] H. A. Schwartz, Chemical composition of malleable iron, Trans. Am. Foundrymen's Assoc. 54, 101 (1946).

[14] P. G. Bastein and L. Guillet, Jr., The influence of some special additions on certain properties of cast iron, Iron \& Steel Inst. Carnegie Scholarship Memoirs 2\%, 77 (1938).

[15] R. S. Dean and B. Silkes, Boron in iron and steel, Information Circular 7363, U. S. Dept. Interior, Bur. Mines (Sept. 1946).

[16] T. G. Digges and F. M. Reinhart, Influence of boron on some properties of experimental and commercial steels, J. Research NBS 39, 67 (1947) RP1815.

[17] A. I. Krynitsky and C. M. Saeger, Jr., Elastic properties of cast iron, J. Research NBS 22, 191 (1939) RP1176.

[18] A. I. Krynitsky and C. M. Saeger, Jr., New method of measuring deflection in the transverse-loading test of cast iron, Bul. Am. Soc. Testing Materials, No. 97, 23 (1939)

[19] A. I. Krynitsky and C. M. Saeger, Jr., Elastic properties of some alloy cast irons, J. Research NBS 28, 73 (1942) RP1147.

[20] A. I. Krynitsky and C. M. Saeger, Jr., Effects of superheating, pouring temperatures and microstructure on the elastic properties of some plain and alloy cast irons, Trans. Am. Foundrymen's Assoc. 50, 451 (1942).

[21] C. K. Donoho, Advances in the foundry industry, Metal Progress 51, 765 (1947).

[22] T. E. Barlow and C. H. Lorig, Gray cast iron tensile strength, Brinell hardness and composition relationship, Trans. Am. Foundrymen's Assoc. 54, 545 (1946).

[23] G. Brinkmann and P. Tobias, Ueber den Zusammensetzung und den mechanischen eigenschaften von gusseisen, Die Giesserei 29, 317 (Sept. 18, 1942).

[24] A. L. Norbury, Constitutional diagrams for cast irons and quenched steels, J. Iron \& Steel Inst. 109, No. 1, 443 (1929).

[25] R. M. Allen, The microscope as a practical aid in the cast iron foundry, Trans. Am. Foundrymen's Assoc. 39, 733 (1931).

[26] N. W. Thibault and Helen L. Nyquist, The measured Knoop hardness of hard substances and factors affecting its determination, Trans. Am. Soc. Metals 38, 271 (1947).

[27] L. P. Tarasov and N. W. Thibault, Determination of Knoop hardness numbers independent of load, Trans. Am. Soc. Metals 38, 331 (1947).

[28] N. F. Tisdale, Boron-a new vitamin for steel and cast iron, Metal Progress 41, 330 (1942).

[29] R. A. Grange and T. M. Garvey, Factors affecting the hardenability of boron-treated steels, Trans. Am. Soc. Metals 37, 136 (1946).

WAshington, January 28, 1949. 